\title{
Short- and long-term effects of fire on the Collembola communities of a sub-alpine dwarf pine ecosystem in the Austrian Alps
}

\author{
Pascal Querner, Alexander Bruckner, Erich Weigand \& Markus Prötsch
}

Keywords: fire ecology, springtails, succession, Kalkalpen National Park

\section{Abstract}

We compared the Collembola communities of three sub-alpine sites in the Limestone Alps to evaluate the short- and long-term effects of natural forest fires. SITE 1 was burned in August 2003, SITE 2 was burned 50 years ago and sampled to assess the long-term effects of fire and the recovery of soil animals. A reference site (REF) was sampled to represent the undisturbed dwarf pine community. All sites are close to each other on a steep slope between 1400 and $1650 \mathrm{~m}$ above sea level. We found a total of 41 species of Collembola, as well as clear differences in the species composition and abundance between the sites. Most species (29) were found on the REF site. The highest abundance was found on SITE 1 (48960 individuals* $m^{-2}, 22$ species). We assume that some species survived the fire in deeper soil layers and others migrated or were passively dispersed from unburned patches and surrounding sites. The lowest abundance and species number (8 160 individuals* $\mathrm{m}^{-2}, 18$ species) were found on the 50 -year-old site. This site was covered with a typical community for moving substratum, consisting mainly of alpine grasses, yet the dwarf pine vegetation had not yet recovered. The soil layer was still very thin and we therefore assume that a recovery of the Collembola community will take much longer than 50 years.
Profile

Protected area

Kalkalpen National Park

Mountain range

Alps

Country

Austria

\section{Introduction}

Fire is a common and destructive disturbance in terrestrial ecosystems. Large wildfires can destroy the aboveground vegetation and also change the belowground physical, chemical and biological properties. Secondary effects like enhanced erosion may result in a further loss of plant biomass and soil nutrients. However, fire is not deleterious for all organisms: some animals and plants are well adapted to this disturbance, for example in the Mediterranean regions and in Australia. Pyrophilous species of insects or fungi may even depend on it to thrive.

Certini (2005) reviews the effects of fires on the forest soil and distinguishes between 1) low to moderate fires and 2) severe fires. Most prescribed fires are of low intensity and can be used as a management tool without long-term effects on organism density and composition. Wildfires, on the contrary, are often of high intensity, occur during dry periods and have much larger and even irreversible effects on the ecosystem. Certini (2005) concludes that if plants succeed in recolonizing a burned site soon after the fire, the pre-fire conditions can recover within a short time. Neary et al. (1999) give a general review on the effects of fire on belowground systems and describe the physical, biogeochemical and biological effects. Low impact fires can encourage herbaceous flora, increase plant available nutrients and thin out overcrowded forests. Severe fires, on the contrary, change the mineralization rate, alter $\mathrm{C}$ to $\mathrm{N}$ ratios, influence above- and belowground species composition, decrease the micro- and macro-

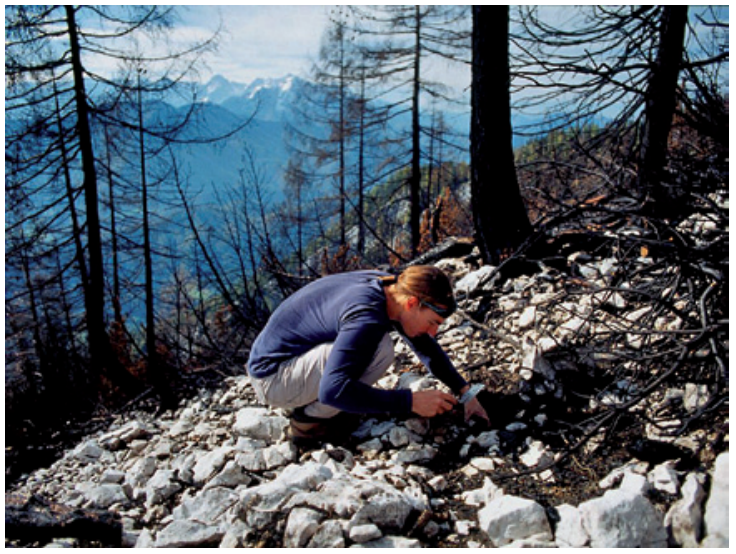

Field work on a burned site in the Austrian Alps. (C) Erich Weigand, Kalkalpen National Park.

fauna and alter the microbial population. Recovery time depends on fire intensity, the effects on key ecosystem processes and components, but also on previous land-use practices. Neary et al. (1999) conclude that the impact of fires can vary greatly and therefore is not predictable. Wildfire occurrences might increase in the future through a global increase in temperature and decrease in rainfall (McKenzie et al. 2004; Brennan et al. 2009; Lutz et al. 2009). Therefore, their importance in disturbance ecology will increase and their impact on ecosystems like national parks should be investigated further.

Collembola (springtails) are small, soil inhabiting, wingless insects. Like other edaphic arthropods, they may be especially affected by fires because they cannot escape the heat and generally depend on moist and 
Table 1 - Species abundance table of the Collembola found in soil samples of three investigation sites of a study on wildfire. SITE 1 is a disturbed site that burned in 2003, SITE 2 burned in 1950 and REF is an undisturbed reference site. Values are individuals $* m^{2}$.

\begin{tabular}{|c|c|c|c|}
\hline Species & SITE 1 & SITE 2 & REF \\
\hline Allacma fusca (Linnaeus, 1758) & 0 & 0 & 80 \\
\hline Anurophorus laricis (Nicolet, 1842) & 0 & 0 & 40 \\
\hline Bourletiella (B.) pistillum (Gisin, 1946) & 0 & 0 & 40 \\
\hline Ceratophysella sp1. & 40 & 0 & 0 \\
\hline Ceratophysella sp2. & 0 & 480 & 0 \\
\hline Desoria sp. & 1520 & 0 & 0 \\
\hline Entomobrya nivalis (Linnaeus, 1758) & 0 & 0 & 40 \\
\hline Entomobrya sp. & 240 & 0 & 560 \\
\hline Folsomia penicula (Bagnall, 1939) & 1680 & 1880 & 3440 \\
\hline Heterosminthurus sp. & 160 & 240 & 0 \\
\hline Hypogastrura cf assimilis (Krausbaver, 1898) & 17320 & 560 & 0 \\
\hline Isotoma sp. & 0 & 440 & 0 \\
\hline Isotomiella minor (Schäffer, 1896) & 2360 & 320 & 7040 \\
\hline Kalaphorura burmeisteri (Lubbock, 1873) & 520 & 0 & 480 \\
\hline Lepidocyrtus cyaneus (Tullberg, 1871) & 2880 & 0 & 40 \\
\hline Lepidocyrtus sp. & 120 & 0 & 200 \\
\hline Lipothrix lubbocki (Tullberg, 1872) & 0 & 0 & 120 \\
\hline Mesaphorura sylvatica (Rusek, 1971) & 3280 & 1640 & 15720 \\
\hline Mesaphorura sp. & 200 & 0 & 1120 \\
\hline Neanura parva (Stach, 1951) & 0 & 40 & 0 \\
\hline Odontella armata (Axelson, 1903) & 360 & 0 & 0 \\
\hline Oligaphorura absoloni (Börner, 1901) & 0 & 360 & 0 \\
\hline Onychiuroides pseudogranulosus (Gisin, 1951) & 1760 & 280 & 80 \\
\hline Onychiurus fimetarius (Linnaeus, 1767) & 920 & 0 & 0 \\
\hline Onychiurus vontoernei (Gisin, 1957) & 1040 & 40 & 2040 \\
\hline Onychiurus juv. & 2440 & 40 & 80 \\
\hline Orchesella montana (Stach, 1960) & 0 & 160 & 0 \\
\hline Parisotoma notabilis (Schäffer, 1896) & 10040 & 1280 & 2320 \\
\hline Pseudachorutes subcrassus (Tullberg, 1871) & 0 & 240 & 80 \\
\hline Pseudanurophorus boerneri (Stach, 1922) & 200 & 0 & 1520 \\
\hline Pseudisotoma sensibilis (Tullberg, 1876) & 0 & 0 & 160 \\
\hline Seira sp. & 0 & 0 & 40 \\
\hline Sminthurides sp. & 40 & 80 & 120 \\
\hline Sminthurus maculatus (Tömösvary, 1883) & 0 & 0 & 40 \\
\hline Tetracanthella stachi (Cassagnau, 1959) & 560 & 0 & 1040 \\
\hline Thaumanura oniscoides (Latzel, 1917) & 0 & 0 & 120 \\
\hline Tomocerus minor (Lubbock, 1862) & 1280 & 40 & 800 \\
\hline Tullbergiinae sp. & 0 & 40 & 0 \\
\hline Willemia anophthalma (Börner, 1901) & 0 & 0 & 160 \\
\hline Willemia denisi (Mills, 1932) & 0 & 0 & 200 \\
\hline Xenylla sp. & 0 & 0 & 5360 \\
\hline Total number of individuals ${ }^{*} \mathbf{m}^{-2}$ & 48960 & 8160 & 43080 \\
\hline Total number of species per site & 22 & 18 & 30 \\
\hline
\end{tabular}

cool conditions in the litter and upper soil layers. The high temperatures of an intense fire usually reach these strata and may destroy the life therein. Most studies investigating the effects of fire on Collembola have been conducted in habitats where fires are a common disturbance, e.g. in Australia (Greenslade 1997; Driessen \& Greenslade 2004) or Finland (Koponen 1988, 1989, 1995; Huhta et al. 1967, 1969). They found recovery times varying between a few to over 20 years, depending on the intensity of the fire.

In the Central Alps, fires are less frequent and a rarely studied disturbance. Gimmi et al. (2004) investigated the fire frequency and Wohlgemuth et al. (2002, 2005) the ecological resilience of the plant and animal communities in the Swiss Alps after a large fire of 300 ha in 2003. Some species there may benefit from the disturbance. Early successional or ruderal species are able to colonize burned sites and species-rich mosaics of spatial patches may develop. Very few species are truly fire-dependent but the rare carabid beetle Agonum bogemanni is an example (Peter Zulka, Vienna Univ., oral comm., September 2006). If the occurrence of wildfires will increase in the future because of climate warming, the Alps will also be effected. This should be con- 
Table 2 - Species (Sorensen Index) and dominance similarity (Bray-Curtis Index) of the Collembola faunas in soil samples of three investigated sites of a study on wildfire. For site codes, see Table 1.

\begin{tabular}{|l|r|r|}
\hline \multicolumn{2}{|l|}{ Bray-Curtis Index } \\
\hline & 21.39 & SITE 2 \\
\hline SITE 2 & 29.38 & - \\
\hline SITE 1 & REF & 21.29 \\
\hline Sørensen Index & 42.55 & SITE 2 \\
\hline \multicolumn{4}{|r|}{} & - \\
\hline SITE 2 & 62.75 & 55.00 \\
\hline SITE 1 & &
\end{tabular}

sidered in conservation and management of protected areas, especially in nature reserves and national parks. A recent wildfire in the Austrian Alps offered the opportunity to investigate the short-term (1 year) and long-term (50 years) effects of high intensity burning in a sub-alpine habitat and to compare the recovery times of the vegetation and the Collembola to studies in other parts of the world. Both sites are close to each other and to an undisturbed reference site, so we assumed that all three had a similar dwarf pine vegetation and Collembola community prior to the fires. As large natural wildfires are rare in the Eastern Alps, no comparable sites were found to replicate the experiment.

\section{Material and Methods}

\section{Study area}

The study area is situated in the north-eastern Limestone Alps in the Sengsengebirge (Kalkalpen National Park; Upper Austria). This mountain range stretches in a roughly east-west direction and rises up to $2000 \mathrm{~m}$. Sub-alpine dwarf pine vegetation (Erico-Pinion mugi Leibundgut 1948) covers its steep south-facing slopes above the timber line. Dwarf pines (Pinus mugo) are dominant here and form an impenetrable thicket, with Winter Heath (Erica carnea) and Hairy Alpine Rose (Rhododendron birsutum) underneath. Individual larch (Larix decidua) and Norway spruce trees (Picea abies) are interspersed among the dwarf pines. The soil is a Tangelrendzina (Austrian soil classification: Kilian 2002), covered with a $15-20 \mathrm{~cm}$ layer of raw humus. We selected three sites on the slope, all close to each other, at altitudes ranging from 1400 to $1650 \mathrm{~m}$.

\section{SITE 1}

In August 2003, an area of 15 ha (centre of the site: $14^{\circ} 18^{\prime} \mathrm{E}, 47^{\circ} 46^{\prime} \mathrm{N}$; SW exposition; slope: $35^{\circ}$ ) burned for 8 days (August 17 to 24) during a very dry weather period, probably due to natural lightning. The fire was fought from the ground and with helicopters, but no retardant was used. During the fire, all dwarf pines, most of the larch trees and large parts of the raw humus layer burned. The rainfall of autumn 2003 and the snow melt in spring 2004 eroded large parts of the remaining soil and ash. The result was a patchy mosaic of soil remnants, rock and scree. At the time of sampling ( 10 months after the fire), the vegetation was very sparse and consisted only of a few remaining or colonizing species (Funaria hygrometrica, Campanula cochleariifolia, Calamagrostis villosa, Erica carnea, Galium anisophyllon, Heleborus niger).

\section{SITE 2}

Close to SITE 1, a similar dwarf pine stand of 12 ha (S exposition; slope $30-40^{\circ}$ ) burned for three weeks from 29 June 1950. We used this area to investigate the long-term effects of fire and the subsequent succession of Collembola for 50 years.

The plant community was dominated by grasses, all other plants appeared in low coverage. Sociologically, it belonged to the association of Athamanto-Trisetum distichophylli (Jenny-Lips 1930) which is typical for moving limestone scree (Seibert 1974; Englisch et al. 1993). In addition, Carex sempervirens and Sesleria albicans were found in high coverage. These two species are typical of the formation of Seslerio-Caricetum sempervirentis (Beger 1922) (Grabherr et al. 1993; Oberdorfer 1974/76) which grows on reposing limestone scree and is often associated and interspersed with the Athamanto-Trisetum distichophylli (Ellenberg 1996).

The dwarf pines, larch trees and Norway spruce trees were not fully recovered and the vegetation was generally patchier than SITE 1. The soil layer was still shallow, probably due to heavy erosion over the last 50 years and the movements of the limestone scree.

\section{REF}

A reference site north of SITE 1 was sampled to represent the undisturbed Collembola fauna. We assume that the Collembola fauna of the REF site was identical to the fauna of SITE 1 and SITE 2 prior to the fire. The tree, shrub and herb layers were well developed at the site. A sparse moss layer was also found. The tree layer consisted of two species, Picea abies and Larix decidua $\left(2.35\right.$ stems $* 100 \mathrm{~m}^{-2}$ ). The shrub layer was dominated by Pinus mugo. Within the herb layer, the acidophilus species Vacinium myrtillus, $V$. vitis-idea and Erica carnea dominated in high coverage and constancy. The plant association was a Homogyno-Piceetum (Zukrigl 1973), which is often found along the timberline in the Northern Alps (Seibert 1988; Mertz 2002).

\section{Field sampling}

Collembola were sampled at the three sites on 26 June 2004, shortly after snowmelt. On each site, ten soil cores were taken with a $57 \times 57 \mathrm{~mm}^{2}$ steel tube (Bruckner 1998) to a depth of $100 \mathrm{~mm}$, stored in plastic bags and cooled until extraction. The cores were taken at random positions with a minimum spacing of $5 \mathrm{~m}$, wherever sufficient substratum was available and within an area of $1000 \mathrm{~m}^{2}$ each site. The samples were taken to the laboratory and extracted in a modified Macfadyen-Extractor for seven days into 10\% benzoic acid solution. The Collembola were transferred 
to $70 \%$ ethanol, counted and identified using the keys of Babenko et al. (1994), Bretfeld (1999), Gisin (1960), Potapow (2001), Stach (1960, 1963), Thibaud et al. (2004) and Zimdars \& Dunger (1994).

\section{Data treatment}

With the full data set, the species similarity of the faunas on the three sites was calculated with the Sørensen Index, and similarity of the dominant species with the Bray-Curtis index. The dominance structure of the communities was compared graphically with rankabundance plots.

Prior to the multivariate data analyses, species with less than three individuals per core were removed from the data (25 species remained); accordingly, two samples (one in SITE 1 and one in REF) were classified as outliers ( $>2$ SD average distance longer than overall mean multivariate distance) and not included in the analysis. Non-metric multidimensional scaling (NMDS, BrayCurtis-similarity, McCune \& Grace 2002: 125ff) was performed to ordinate the individual samples along axes in multidimensional species space and separate the three sites. We tested for significant differences between the three faunas in ordination space with a nonparametric procedure (MRPP; multi-response permutation procedure, McCune and Grace 2002: 188ff). We used PRIMER 5.2.9 (Clarke \& Gorley 2001) for the calculation of the Sørensen and Bray-Curtis Index, and PC-ORD 4.25 (McCune \& Mefford 1999) for the multivariate analyses.

\section{Results}

We collected 2505 Collembola specimens in the soil samples. They belonged to 41 species (Table 1). Clear differences were found in total Collembola abundance and species richness among the three sites: SITE $1 \mathrm{had}$ the highest abundance of 48960 individuals $* \mathrm{~m}^{-2}$ and 22 species. Hypogastrura of assimilis, Parisotoma notabilis and Mesaphorura sylvatica were the most abundant species. SITE 2 showed the lowest number of individuals $\left(8160 * \mathrm{~m}^{-2}\right)$ and also the lowest species richness (18). Folsomia penicula, Mesaphorura sylvatica and Parisotoma notabilis were the most abundant species.

The highest species richness was found on the REF site with 29 species and a high abundance of 43080 individuals $* \mathrm{~m}^{-2}$. Mesaphorura sylvatica, Xenylla sp. and Isotomiella minor were the most abundant species.

Species similarity (Sørensen Index, Table 2) was moderately high between the REF and SITE 1 faunas; lower between the SITE 1 and SITE 2 faunas; and lowest between REF and SITE 2. The similarity of the dominants (Bray-Curtis Index, Table 2) was low between REF and SITE 2 and between SITE 1 and SITE 2; and slightly higher between REF and SITE 1. The rank-abundance plots of the three sites are approximately linear and very similar (Figure 1). A small number of dominant species makes up a large proportion of the catch. Most other species occur in inter- mediate to low abundance. Therefore, the fire did not affect the dominance structure of the site faunas.

The ordination of the 28 samples with the non-metric multidimensional scaling (NMDS) did not reveal a strong multivariate gradient separating the three sites along any of the axes. Indistinct site clusters are evident, however, in plots of the first three axes (Figure 2). This clustering was significant (MRPP; $\mathrm{T}=-11.17$, $\left.\mathrm{p}=2 * 10^{-8}\right)$.

\section{Discussion}

We found substantial compositional differences between the Collembola faunas of the three investigated sites. This shows that fires may have significant shortand long-term effects on the Collembola communities in sub-alpine habitats.

The result of low abundance and species richness at SITE 2, compared to the reference site, is initially surprising, as we would have expected extensive recovery of the Collembola community after 50 years of post-fire succession. Other authors found much faster recovery times: Sgardelis \& Margaris (1993), Majer (1984), Metz \& Farrier (1973) and Seastedt (1984) estimated short recovery times (3-4 years) after controlled and less destructive fires. Jahn et al. (1970) investigated the succession of Collembola on another burned alpine site (Tyrol, Austria, 1600-2137 m), the only other study investigating the effect of fire on Collembola in the Alps. They found that the number of individuals and species declined in the first year and was still lower eleven years after the fire, but had recovered after twenty years. Koponen (1988, 1989 and 1995) found lower densities of springtails and mites, instable and divergent communities four years after a fire in Finland. Similar results were presented by Huhta et al. (1967, 1969) in central Finland, where seven years were insufficient for the communities to recover. But Koponen and Huhta et al. only investigated short-term effects and did not sample after longer recovery times. Long-term effects $(8-11$ and 27 years) were investigated by Driessen \& Greenslade (2004) in Australian lowland grasslands. They found some differences in the species composition in the younger regrowth site but not in the older site. Shaw (1997) found depauperate communities on two sites that burned twenty years ago and again five years prior to sampling. He also described a strong rise of Collembola densities three months after a shallow fire and accounted for this with enhanced egg germination due to the fire. The recovery times of Collembola communities found by other authors varied greatly and probably depended mainly on the intensity of the fire but also on the seasonality of the fire and the local adaptation of the habitat to this disturbance.

However, if secondary effects of the fire are consider$\mathrm{ed}$, the reasons for the slow recovery of the fauna on SITE 2 are obvious and correspond to the development of vegetation. The soil was probably denuded 


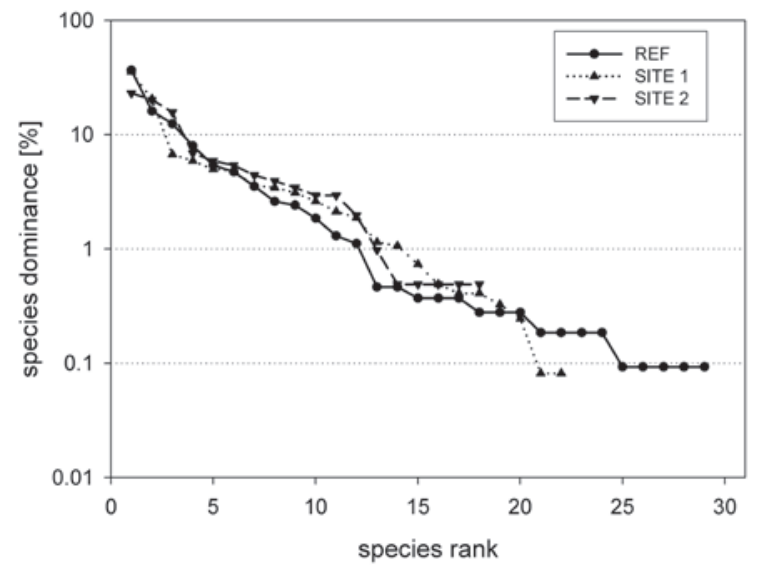

Figure 1 - Rank-abundance curve for the Collembola from three investigation sites of a wildfire study. For site codes, see Table 1.

after the fire of 1950 and, because of the steep inclination, heavy rains and intensive snow melt each spring, the soil developing processes were retarded afterwards. A shallow soil layer discourages the development of larger plants, which by itself would stop erosion more effectively. As a result of the missing humus layer, the rocks become destabilized (Conedera 2005), creating a moving substratum on the steep slopes. This also prevented the original vegetation from recolonizing the site. Limestone and the shallow humus body below the rock contain sufficient nutrients (Zöttl 1952) but only few plant species can survive on moving rubble. This substratum can only be colonized by species able to dam up moving rocks, wander downward or overgrow the moving scree. A change to alpine grassland and later to the original dwarf pine is only possible when rock fall has stopped. This succession is not expected within the next centuries due to the very short vegetation period each year (June to September).

In our case we found a long-term reduction in the quality of the ecosystem. But small and short fires might also improve the quality of the whole ecosystem when a larger area, such as the entire national park, is considered. Small wildfires can enhance the total species richness when new species can establish themselves at the site and a more diverse mosaic of microhabitats can develop. In contrast, long and large fires should be prevented by the management of the national park as they favour erosion processes. We found a severe impact on the soil animal community that could result in a lower soil quality.

The short grass vegetation and shallow soil layer of SITE 2 exhibit a more extreme microclimate than the dwarf pine stand and can affect the Collembola community indirectly: 1) higher temperatures occur in summer due to the steep inclination and southern exposition, 2) colder temperatures occur in winter due to lack of a buffering dwarf pine layer, and 3) drought occurs because the soil layer is too thin to store significant amounts of humidity and limestone itself does not hold water. 4) Wind action can be expected to be another major factor. This also coincides with the hypothesis of Certini (2005) and Webb (1994) that the recovery time of the animal assemblages after fires depends very much on the recovery of the vegetation. As a result of these secondary effects, we predict a decline of the number of species and abundance for SITE 1 over the next 50 years towards a community similar to that of SITE 2. These results contradict those of Wolgemuth et al. (2005) and Schönenberger \& Wasem (1997) who reported a rather fast recovery of the plant cover of burned sites in Wallis (southern Switzerland). Especially Calamagrostis varia was found within one year in their sites. This plant may derive from surviving rhizomes below the ash layer (Wolgemuth et al. 2005). On the site in Austria, the soil layer was almost completely destroyed by the fire of 2003 and we do not expect a recovery from the seed bank or surviving rhizomes.

The recently burned SITE 1 exhibited high Collembola abundance and species number. This was unexpected, since the fire severely reduced the humus layer, and we expected it to have a devastating impact on the soil fauna. Hypogastrura of assimilis, Parisotoma notabilis and Mesaphorura sylvatica were the dominant species at this site and seem to benefit from the disturbance or were
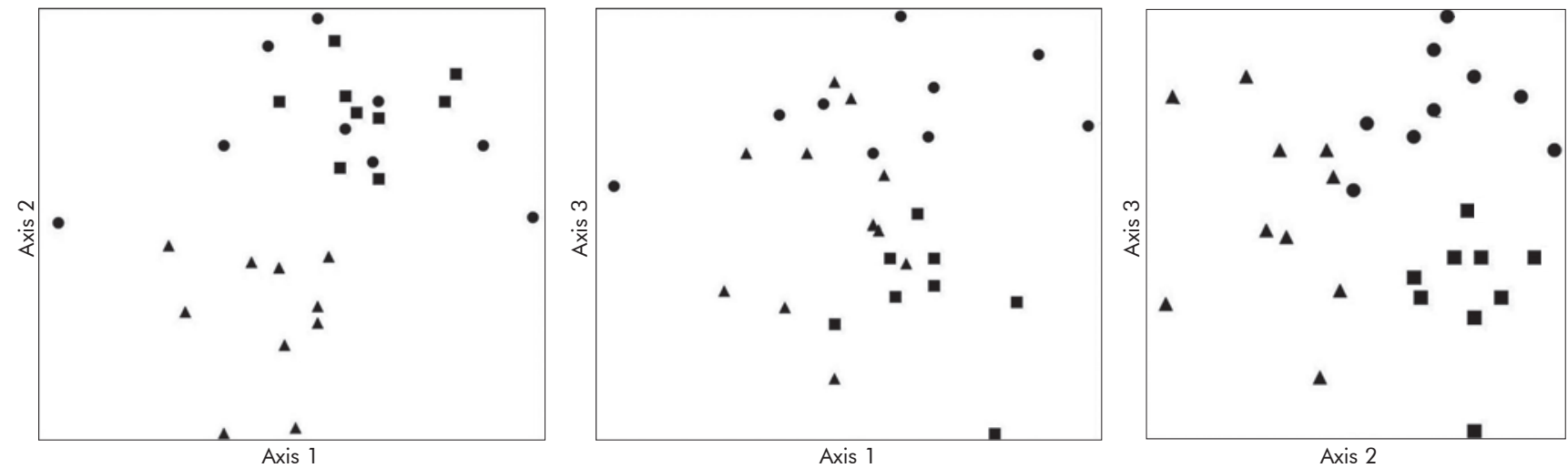

Figure 2 - Ordination of 25 samples along (a) axes 2 and 1, (b) axis 3 and 1 and (c) axis 3 and 2 in a multidimensional space (non-metric multi-

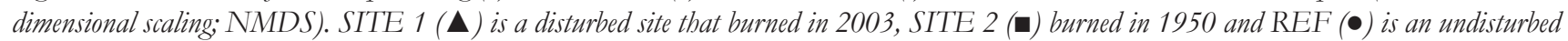
reference site. 


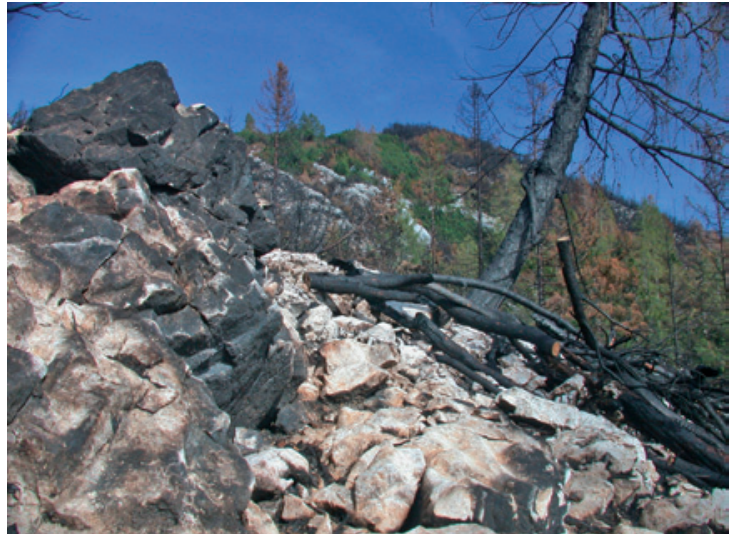

Effects of fire on a sub-alpine dwarf pine ecosystem in the Austrian Alps. (C) Erich Weigand, Kalkalpen National Park.

the first to recolonize the site. Hypogastrura of assimilis is described as a eurytopic species, Parisotoma notabilis is one of the most ubiquist species and Mesaphorura sylvatica also occurs widely, both are found in all kinds of habitats. None of these species is specific to the early stages of the succession (few studies have investigated succession of Collembola in the Alps). Folsomia penicula, Mesaphorura sylvatica and Parisotoma notabilis were the dominant species of the 50-year old burned site. In the future it should be investigated if this is a stable climax community. Folsomia penicula is described as mesophilic, is mostly a forest species and usually found in high abundances. Mesaphorura sylvatica, Xenylla sp. and Isotomiella minor are the dominant species of the undisturbed site and this should be part of a stable climax community. Xenylla sp. was not identified to species level (it may be a new species) so we cannot say anything about its ecology. Both Mesaphorura sylvatica and Isotomiella minor are not typical Alpine species. Isotomiella minor is also described as one of the most ubiquist species and occurs in all kinds of habitats. After Deharveng (oral comm. at the Aperygota conference in Siena, September 2010), Parisotoma notabilis and Isotomiella minor each are probably a group of species.

Our findings indicate that survival of resident species and immigration from outside may have a role in this: 1) Collembola may have survived the fire in deeper soil layers. They are known to migrate into deeper soil layers (up to $10 \mathrm{~cm}$ ) during unfavorable conditions, for example heat or drought (Hopkin 1997: 168). As the fire occurred in a very hot and dry summer period, animals might have survived within the site. Webb (1994) showed in experimental fires that the heat does not penetrate deeper than $5 \mathrm{~cm}$ into the soil and that microarthropods can survive. 2) Active migration / recolonization over short distances from the small unburned patches within the site (as proposed by Bellido 1987 or Shaw 1997) and / or from the surrounding unharmed dwarf pine stands is possible, since microarthropods can migrate a few meters within a short time (Hågvar 1995). 3) Passive dispersal of animals with water and soil substrate after heavy rains and snowmelt from upslope areas was probably the most important factor. As Collembola can be active under the snow cover (Aitchison 1979, 1984) and reproduce fast (Hopkin 1997: 133), they had enough time to recover during the ten months after the fire. Our results underline the fact that identification to species level provides much deeper ecological insights than the mere counting of individuals. We found similar abundances on SITE 1 and the REF site, but the species compositions were significantly different. Conclusions in the literature on the recovery times, based on abundances only, do not account for the potential extinction of certain species, recolonization by others and compositional changes in the community as a whole. Even the identification of morpho-species, as done in Australia by Greenslade \& Driessen (1999), can give a better resolution.

We are aware that the successional stages in our investigation were not replicated, so that the generality of the results is debatable. Larger studies with a detailed resolution of chronosequences are needed to investigate further the long-term effects of fires on Collembola in the Alps and to test the prediction of a species loss within 50 years after the fire. Sites older than 50 years could reveal the time needed to reach an ecological climax. The only study in the Alps sampling a large number of sites at different successional stages was done by Moretti et al. (2004), who sampled 22 sites in the southern Alps of Switzerland to investigate the effects of single and repeated forest fires on the species richness of ground beetles, hoverflies, bees, wasps, spiders, bugs and lacewings. In Australia, Greenslade \& Driessen (1999) sampled 27 Buttongrass moorland sites for the Collembola communities with a chronosequence ranging from one month to 64 years since the last fire.

Friend (1996) suggested in his review six invertebrate groups (spiders, butterflies, isopods, Isoptera, Thysanoptera and Blattodea) as indicator groups for fire disturbances.

\section{Acknowledgements}

The project was funded by the Theodor Körner Fond of the City of Vienna (2004). We also thank Cristina Lazcano for help in the field and Richard Hobbs and Sandrine Petit for their comments on the manuscript.

\section{References}

Aitchison, C.W. 1979. Winter-active subnivean invertebrates in central, southern Canada. I. Collembola. Pedobiologia 19: 113-120.

Aitchison, C.W. 1984. The phenology of Collembola from south central Canada. Pedobiologia 27: 405-423.

Babenko, A.B., N.M. Chernova, M.B. Potapov \& S.K. Stebaeva 1994. Collembola of Russia and adjacent countries: Family Hypogastruridae. Nauka, Moscow.

Bellido, A. 1987. Field experiment about direct effect of a heathland prescribed fire on microarthro- 
pod community. Revue d'Écologie et de Biologie du sol 24: 603-622.

Brennan, K.E.C., F.J. Christie \& A. York 2009. Global climate change and litter decomposition: More frequent fire slows decomposition and increases the functional importance of invertebrates. Global Change Biology 15: 2958-2971.

Bretfeld, G. 1999. Synopses on Palaearctic Collembola. Volume 2. Symphypleona. Abhandlungen und Berichte des Naturkundemuseums Görlitz 71.

Bruckner, A. 1998. Augers may bias field samples of soil mesofauna. Pedobiologia 42: 309-315.

Certini, G. 2005. Effects of fire on properties of forest soils: a review. Oecologia 143: 1-10.

Clarke, K.R. \& R.N. Gorley 2001. PRIMER v5: User Manual/Tutorial. PRIMER-E, Plymouth.

Conedera, M. 2005. Erosion und Oberflächenabfluss nach Bränden. Bündnerwald 58: 75-76.

Driessen, M.M. \& P. Greenslade 2004. Effect of season, location and fire on Collembola communities in buttongrass moorlands, Tasmania. Pedobiologia 48: 631-642.

Ellenberg, H. 1996. Vegetation Mitteleuropas mit den Alpen in ökologischer, dynamischer und bistorischer Sicht. Stuttgart.

Englisch, T., M. Valachovič, L. Mucina, G. Grabherr \& T. Ellmauer 1993. Thlaspietea rotundifolii. In: Grabherr, G. \& L. Mucina (eds.), Die Pflanzengesellschaften Österreichs. Teil II. Jena: 276-342.

Friend, G. 1996. Fire ecology of invertebrates: implications for nature conservation, fire management and future research. In: Fire and Biodiversity: the Effects and Effectiveness of Fire Management: Proceedings of the Conference Held 8-9 October, 1994, Footscray, Melbourne. Department of the Environment, Sport and Territories, Australia: 155-162.

Gimmi, U., M. Bürgi \& T. Wohlgemuth 2004. Wie oft brannte der Walliser Wald im 20. Jahrhundert? Schweizerische Zeitschrift für Forstwesen 155: 437-440.

Gisin, H. 1960. Collembolenfauna Europas. Museum d'Histoire Naturelle, Genève.

Grabherr, G., J. Greimler \& L. Mucina 1993. Seslerietae albicantis. In: Grabherr, G. \& L. Mucina (eds.), Die Pflanzengesellschaften Österreichs. Teil II. Jena: 402-446.

Greenslade, P. 1997. Short term effects of a predescribed burn on invertebrates in grassy woodland in South-Eastern Australia. Memoirs of the Museum of Victoria 65: 305-312.

Greenslade, P. \& D. Driessen 1999. The effect of fire on epigaeic arthropods in Buttongrass moorlands in Tasmania. In: Ponder, W. \& D. Lunney (eds.), The Other 99\%. The Conservation and Biodiversity of Invertebrates. Transactions of the Royal Zoological Society of New South Wales: 82-89.

Hågvar, S. 1995. Long distance, directional migration on snow in a forest collembolan, Hypogastrura socialis (Uzel). Acta Zoologica Fennica 196: 200-205.

Hopkin, S.P. 1997. Biology of the Springtails. Oxford.
Hutha, V., E. Karppinen, M. Nurminen \& A. Valpas 1967. Effect of silvicultural practices upon arthropod, annelid and nematode populations in coniferous forest soil. Annales Zoologici Fennici 2: 87-145.

Huhta, V., M. Nurminen \& A. Valpas 1969. Further notes on the effect of silvicultural practices upon the fauna of coniferous forest soil. Annales Zoologici Fennici 6: $327-334$.

Jahn, E., H.M. Schiechtl \& G. Schimitschek 1970. Möglichkeiten der natürlichen und künstlichen Regeneration einer Waldbrandfläche in den Tiroler Kalkalpen. Berichte des naturwissenschaftlich-medizinischen Vereins Innsbruck. 58: 355-388.

Kilian, W. 2002. Schlüssel zur Bestimmung der Böden Österreichs. Mitteilungen der Österreichischen Bodenkundlichen Gesellschaft 67: 1-96.

Koponen, S. 1988. Effects of fire on spider fauna in subarctic birch forest, northern Finland. Technische Universität Berlin. Dokumentation Kongresse Tagungen 38: 148-153.

Koponen, S. 1989. Effect of fire on ground layer invertebrate fauna in birch forest in the Kevo Strict Sature Reserve, Finnish Lappland. Folia forestalia 736: 75-80.

Koponen, S. 1995. Postfire succession of soil arthropod groups in a subarctic birch forest. Acta Zoologica Fennica 196: 243-245.

Lippert, W. 1966. Die Pflanzengesellschaften des Naturschutzgebietes Berchtesgaden. Berichte der Bayerischen Botanischen Gesellschaft 39: 67-122.

Lussenhop, J.F. 1976. Soil arthropod responce to prairie burning. Ecology 57: 88-98.

Lutz, J.A., J.W. Van Wagtendonk, A.E. Thode, J.D. Miller \& J.F. Franklin 2009. Climate, lightning ignitions, and fire severity in Yosemite National Park, California, USA. International Journal of Wildland Fire 18: 765-774.

Majer, J.D. 1984. Short term responses of soil and litter invertebrates to a cool autumn burn in Jarrah (Eucalyptus marginata) forest in Western Australia. Pedobiologia 26: 229-247.

McCune, G. \& M.J. Mefford 1999. PC-ORD. Multivariate analysis of ecological data, v4.0. MjM Software Design, Gleneden Beach, Oregon, USA.

McCune, B. \& J.B. Grace 2002. Analysis of Ecological Communities. MjM Software Design, Gleneden Beach, Oregon, USA.

McKenzie, D., Z. Gedalof, D.L. Peterson \& P. Mote 2004. Climatic change, wildfire, and conservation. Conservation Biology 18: 890-902.

Metz, L.J. \& M.H. Farrier 1973. Prescribed burning and populations of soil mesofauna. Environmental Ecology 2: 433-440.

Mertz, P. 2002. Pflanzengesellschaften Mitteleuropas und der Alpen, Erkennen, Bestimmen, Bewerten, Ein Handbuch für die vegetationskundliche Praxis. Hamburg.

Moretti, M., K.M. Obris \& P. Duelli 2004. Arthropod biodiversity after forest fires: winners and losers 
in the winter fire regime of the southern Alps. Ecography 27: 173-186.

Neary, D.G., C.C. Klopatek, L.F. DeBano \& P.F. Ffolliott 1999. Fire effects on belowground sustainability: a review and synthesis. Forest Ecology and Management 122: 51-71.

Oberdorfer, E. 1974 / 76. Seslerietae variae. In: Oberdorfer, E. (ed.), 1993. Süddeutsche Pflanzengesellschaften, Teil II: 194-203.

Potapow, M. 2001. Synopses on Palaearctic Collembola. Volume 3. Isotomidae. Abhandlungen und Berichte des Naturkundemuseums Görlitz 73.

Schönenberger, W. \& U. Wasem 1997. Die Wiederbewaldung der Brandfläche Müstair. Cratschla 2: 9-14.

Seastedt, T.R. 1984. Microarthropods of burned and unburned tallgrass prairie. Journal of the Kansas Entomological Society 57: 468-476.

Seibert, P. 1974. Thlaspietea rotundifolii. In: Oberdorfer, E. (ed.), 1977. Süddeutsche Pflanzengesellschaften, Teil I: 42-66.

Seibert, P. 1988. Vaccinio-Piceetea. In: Oberdorfer, E. (ed.), 1992. Süddeutsche Pflanzengesellschaften, Teil IV: 53-80.

Sgardelis, S.P. \& N.S. Margaris 1993. Effects of fire on soil microarthropods of a phryganic ecosystem. Pedobiologia 37: 83-94.

Shaw, P.J.A. 1997. Post-fire successions of Collembola in lowland heaths in South-Eastern UK. Pedobiologia 41, 80-87.

Stach, J. 1960. The Apterygotan Fauna of Poland in Relation to the World-Fauna of this group of Insects. Tribe: Orchesellini. Polska Akademia Nauk, Kraków.

Stach, J. 1963. The Apterygotan Fauna of Poland in Relation to the World-Fauna of this group of Insects. Tribe: Entomobryini. Polska Akademia Nauk, Kraków.

Thibaud, J.M., H.J. Schulz \& M.M. da Gama Assalino 2004. Synopses on Palaearctic Collembola. Volume 4. Hypogastruridae. Abhandlungen und Berichte des Naturkundemuseums Görlitz 75.

Webb, N.R. 1994. Post-fire succession of Cryptostigmatic mites (Acari, Cryptostigmata) in a Callunaheathland soil. Pedobiologia 38: 138-145.

Wohlgemuth, T., M. Bürgi, C. Scheidegger \& M. Schütz 2002. Dominance reduction of species through disturbance - a proposed management principle for central European forests. Forest Ecology and Management 166: 1-15.

Wohlgemuth, T., P. Duelli, C. Ginzler, I. Gödickmeier, S. Hadorn, F. Hagedorn, P. Küttel, P. Lüscher, M. Moretti, G. Schneiter, S. Sciacca \& B. Wermelinger 2005. Ökologische Resilienz nach Feuer: Die Waldbrandfläche Leuk als Modellfall. Schweizerische Zeitschrift für Forstwesen 156: 345-352.

Zimdars, B. \& W. Dunger 1994. Synopses on Palaearctic Collembola. Volume 1. Tullberginae. Abhandlungen und Berichte des Naturkundemuseums Görlitz 68.

Zöttl, H. 1952. Beitrag zur Ökologie alpiner Kalkschuttstandorte. Phyton 4: 160-175.
Zukrigl, K. 1973. Montane und subalpine Waldgesellschaften am Alpenostrand. Mitteilungen der Forstlichen Bundesversuchsanstalt 101: 1-387.

\section{Authors}

Pascal Querner ${ }^{1}$ - corresponding author studied biology at Vienna University and in his thesis specialized in Collembola (springtails). His main interests are the effects of the composition and changes of landscapes on the Collembola community and diversity. Such landscape scale changes include habitat fragmentation, natural fires, landscape composition or dispersal across the landscape. In his $\mathrm{PhD}$ at the University of Natural Resources and Life Sciences $(\mathrm{BOKU})$ he investigated different landscape-ecological effects on springtails in oilseed rape fields in eastern Austria.

pascal.querner@boku.ac.at

\section{Alexander Bruckner ${ }^{1}$}

trained in zoology and soil science and works as assistant professor at the University of Natural Resources and Life Sciences in Vienna. His research focuses on the community ecology of soil biota (animals and microorganisms) and various other aspects of soil ecology.

\section{Erich Weigand}

is a biologist currently working at the Kalkalpen $\mathrm{Na}$ tional Park in Austria where he is coordinating different research projects on the animal and plant diversity in different habitats. Nationalpark Oberösterreich Kalkalpen Ges.m.b.H. Nationalpark Allee 1, A-4591 Molln, Austria.

Markus Prötsch

is a biologist working at the Natural History Museum Haus der Natur in Salzburg where he is engaged in different teaching and educations tasks. $\mathrm{He}$ is also interested in the botany of mountain habitats like the Kalkalpen National Park. Museum Haus der Natur Museumsplatz 5, A-5020 Salzburg, Austria.

${ }^{1}$ Soil Ecology Group, Institute of Zoology, Department of Integrative Biology. University of Natural Resources and Applied Life Sciences. Gregor-MendelStr. 33, A-1180 Vienna, Austria. 